\title{
KARAKTERISTIK DAN LINGKUNGAN PENGENDAPAN BATUBARA BERDASARKAN ANALISIS PETROGRAFI ORGANIK, DAERAH JONGGON, KABUPATEN KUTAI KARTANEGARA, PROVINSI KALIMANTAN TIMUR
}

\author{
CHARACTERISTICS AND DEPOSITIONAL ENVIRONMENT OF COAL \\ BASED ON ORGANIC PETROGRAPHY ANALYSIS, JONGGON AREA, \\ KUTAI KARTANEGARA REGENCY, EAST KALIMANTAN PROVINCE
}

\author{
Agus Maryono dan Sigit A. Wibisono \\ Pusat Sumber Daya Mineral, Batubara dan Panas Bumi \\ mryaguspsdmbp@gmail.com
}

\begin{abstract}
ABSTRAK
Karakteristik (peringkat dan tipe) serta lingkungan pengendapan batubara di daerah Jonggon dan sekitarnya diteliti dengan menggunakan metode petrografi batubara (analisis reflektansi vitrinit dan komposisi maseral). Analisis dilakulan terhadap 13 conto batubara formasi Balikpapan. Secara megaskopis batubara berwarna hitam, keras, goresan hitam, agak kusam, pecahan blocky, terdapat getah damar, ketebalan berkisar 0,40 m s.d. 3,30 m. Analisis reflektansi vitrinit (Rv) menunjukkan bahwa batubara di daerah penelitian memiliki nilai Rv berkisar antara $0,25 \%$ s.d. $0,45 \%$ sehingga dapat diklasifikasikan pada peringkat lignit subbituminous. Secara mikroskopis, analisis komposisi maseral menunjukan bahwa tipe batubara di daerah penelitian didominasi oleh kelompok maseral huminit $(67,60 \%$ s.d. $95,80 \%)$, diikuti oleh maseral inertinit (1,20 s.d. $26,40 \%)$ serta sebagian kecil maseral liptinit $(0,20 \%$ s.d. $5,60 \%)$. Lebih jauh, hasil analisis komposisi maseral melalui nilai Tissue Preservation Index (TPI), Gelification Index (GI), dan Ground Water Index (GWI) mengindikasikan bahwa material organik pembentuk batubara di daerah penelitian didominasi oleh tumbuhan berkayu yang mengalami tingkat oksidasi rendah serta terendapkan pada lingkungan telmatik.
\end{abstract}

Kata kunci: batubara, petrografi organik, lingkungan pengendapan, reflektansi vitrinit

\begin{abstract}
Characteristics (rank and type) as well as the coal depositional environment in Jonggon and surrounding areas were investigated using coal petrographic methods (vitrinite reflectance and maceral composition analyses). The analysis was conducted on 13 coal samples of Balikpapan formation. Megascopically coal has black appearance, hard, black streaks, slightly dull, blocky, contain resin, with thickness ranging from 0.40 to $3.30 \mathrm{~m}$. Vitrinite reflectance (Rv) analysis shows that coal in the study area has $R v$ values ranging from $0.25-0.45 \%$ so that it is classified into lignite - subbituminous rank. Microscopically, maceral composition analyses show that coal in the area is dominated by the huminite maceral group (67.60 - 95.80\%), followed by inertinite maseral (1.20 - 26.40\%) and a small portion of liptinite maseral $(0.20$ $5.60 \%)$. Furthermore, the results of the maceral composition analysis through the value of Tissue Preservation Index (TPI), Gelification Index (GI), and Ground Water Index (GWI) indicate that the coal-forming organic material in the research area is dominated by woody plants that experience low oxidation and deposited in telmatic environment.
\end{abstract}

Keywords: coal, organic petrographic, depositional environment, vitrinite reflectance 


\section{PENDAHULUAN}

Batubara didefinisikan sebagai kelompok batuan sedimen organik yang terdiri atas material tumbuhan yang telah mengalami proses pembatubaraan dan dibedakan menjadi jenis humik serta sapropelik (Diessel, 1992). Batubara humik umumnya diendapkan di lingkungan darat dengan proses pengendapan di tempat asal terbentuknya (autochthonous) atau telah mengalami proses transportasi (allochthonous), sedangkan batubara sapropelik umumnya diendapkan di lingkungan laut dan lingkungan lakustrin air tawar, seperti cannel coal dengan proses pengendapan apungan (Diessel, 1992).

Material organik dalam batubara yang dapat teramati di bawah mikroskop disebut sebagai maseral. Berdasarkan komposisi kimia, warna pantul, bentuk morfologi, ukuran, relief, struktur dalam, intensitas refleksi, dan tingkat pembatubaraan, maseral dikelompokan menjadi 3 grup utama yaitu vitrinit, liptinit, dan inertinit (Stach dkk., 1982).

Secara fisik, karakteristik batubara dapat tergambar melalui tingkat kematangan (peringkat batubara) dan komposisi material organik penyusunnya. Pemahaman mengenai peringkat dan tipe batubara dapat membantu dalam memberikan arahan pemanfaatan dan pengolahan batubara maupun strategi eksplorasi batubara di masa yang akan datang=

Analisis petrografi batubara merupakan satu metode yang dapat digunakan untuk menentukan karakteristik batubara berupa peringkat dan tipe batubara. Lebih jauh, komposisi maseral atau tipe batubara juga biasa digunakan untuk menentukan lingkungan pengendapan batubara (Cook, 1982; Diessel, 1992; Amijaya dan Littke, 2005; Baihaqi dkk., 2017). Lingkungan pengendapan batubara dapat diidentifikasi berdasarkan nilai TPI dan GI. TPI atau indeks jaringan terawetkan merupakan perbandingan antara struktur jaringan maseral yang terawetkan dengan struktur jaringan yang tidak terawetkan atau terdegradasi, sedangkan GI atau indeks gelifikasi merupakan perbandingan antara maseral yang terbentuk akibat proses gelifikasi dan maseral yang terbentuk karena proses oksidasi yang berhubungan dengan kontinuitas kelembapan pada suatu lahan gambut. Gabungan antara nilai TPI dan GI dapat digunakan dalam penentuan lingkungan pengendapan dan memperkirakan derajat dekomposisi (Diessel, 1992). Diessel (1992), membagi lingkungan pengendapan batubara menjadi tiga yaitu lingkungan pengendapan telmatik (terrestrial), limnik, dan laut (marine).

Selain itu, komposisi maseral dapat dipergunakan pula untuk mengindentifkasi vegetasi yang tumbuh pada lahan gambut berdasarkan nilai GWI dan VI. GWI atau indeks air tanah merupakan perbandingan antara jaringan yang mempunyai tingkat gelifikasi kuat terhadap jaringan yang mengalami gelifikasi lemah. Nilai GWI dapat digunakan untuk memperlihatkan tingkat gelifikasi yang mengindikasikan keadaan $\mathrm{pH}$ dan suplai air pada suatu lahan gambut. $\mathrm{VI}$ atau indeks vegetasi dapat digunakan sebagai petunjuk dalam mengindikasikan asal mula pembentukan suatu lahan gambut (Diessel, 1992).

Analisis petrografi batubara dilakukan terhadap batubara Formasi Balikpapan di daerah Jonggon dan sekitarnya (Gambar 1) dengan tujuan untuk mengetahui karakteristik peringkat dan tipe batubara serta untuk memperkirakan lingkungan pengendapan batubara di daerah tersebut

\section{GEOLOGI DAERAH PENELITIAN}

Daerah penelitian merupakan bagian dari Cekungan Kutai (Gambar 2) yang dibatasi oleh Cekungan Tarakan di bagian utara, bagian selatan dibatasi oleh Cekungan Barito, bagian timur dibatasi oleh Selat Makassar, dan bagian barat dibatasi oleh Cekungan Ketungau dan Cekungan Melawi (Satyana dkk., 1999). Struktur yang berkembang di daerah penelitian berupa perlipatan (Supriatna dkk., 1995). 


\section{MAKALAH ILMIAH}

Stratigrafi daerah penelitian terdiri atas tiga Formasi dari tua ke muda yaitu Formasi Pamaluan (Tomp), Formasi Pulubalang (Tmpb), dan Formasi Balikpapan (Tmbp). Batubara pada daerah penelitian ditemukan pada Formasi Balikpapan (Tmbp) berumur Miosen Tengah - Miosen Akhir (Gambar 3).

Formasi Balikpapan (Tmbp) terdiri atas litologi batupasir, batulempung, batugamping, dan batubara (Supriatna dkk., 1995). Batubara yang ditemukan di daerah penelitian mempunyai beberapa ciri kenampakan megaskopis yaitu berwarna hitam, keras, goresan hitam, agak kusam, pecahan blocky, terdapat getah damar, kontak atas tegas dengan batupasir, dan kontak bawah tegas dengan batulempung, dengan tebal berkisar $0,40 \mathrm{~m}$ s.d. $3,30 \mathrm{~m}$.

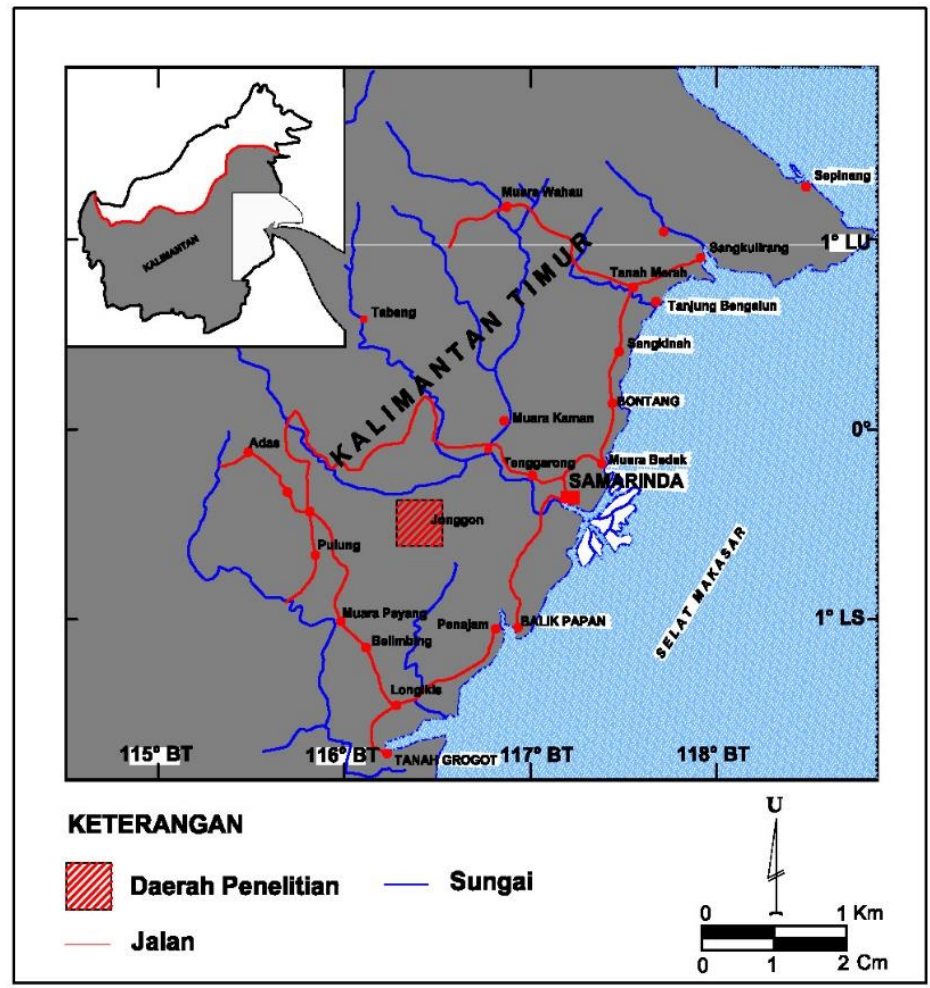

Gambar 1. Peta lokasi daerah penelitian

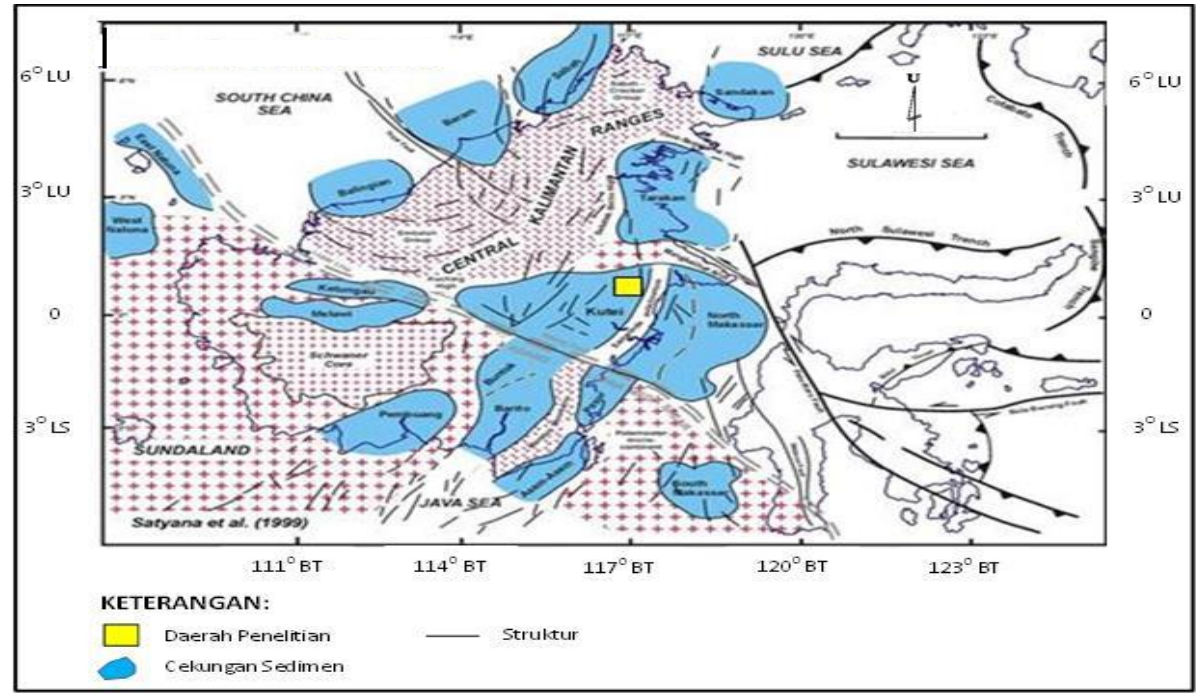

Gambar 2. Peta fisiografi Pulau Kalimantan (Satyana dkk., 1999) 


\section{DATA DAN METODOLOGI}

Identifikasi karakteristik dan lingkungan pengendapan batubara di daerah penelitian didasarkan pada hasil analisis petrografi organik terhadap 13 conto yang mewakili 7 seam batubara pada Formasi Balikpapan yang dilakukan di laboratorium Pusat Sumber Daya Mineral, Batubara dan Panas Bumi (PSDMBP).

Analisis petrografi organik berupa analisis reflektansi vitrinit untuk penentuan rank atau peringkat batubara dan analisis komposisi maseral untuk mengetahui tipe dan lingkungan pengendapan batubara. Pengukuran nilai reflektansi vitrinit mengacu pada ASTM D2798 (2011). Hasil analisis komposisi maseral digunakan untuk menentukan nilai TPI, GI, GWI, dan VI dengan mengadopsi formula dari Diessel (1992) yang telah dimodifikasi oleh Amijaya dan Littke (2005) untuk klasifikasi batubara peringkat rendah (brown coal). Formula yang digunakan adalah sebagai berikut:

(1) $\mathrm{TPI}=\frac{\text { (Telohuminit + Teloinertinit) }}{(\text { Humodetrinit }+ \text { Humokolinit }+ \text { Inertodetrinit + Geloinertinit) }}$
(2) $\mathrm{GI}=\frac{\text { (Huminit }+ \text { Geloinertinit) })}{(\text { Inertinit) }}$
(3) $\mathrm{GWI}=\frac{\text { Korpohuminit }+ \text { Bahan Mineral }}{\text { Telinit }+ \text { Ulminit }+ \text { Detrohuminit }}$
(4) $\mathrm{VI}=\frac{\text { Telohuminit }+ \text { Semifusinit }+ \text { Fusinit }+ \text { Suberinit }+ \text { Resinit }}{\text { Detrohuminit }+ \text { Inertodetrinit }+ \text { Liptodetrinit }+ \text { Sporinit }+ \text { Kutinit }+ \text { Alginit }}$

Analisis petrografi organik batubara dilakukan pada blok poles batubara dengan menggunakan mikroskop sinar pantul Carl Zeiss Axioplan yang terkoneksi dengan komputer dan alat penghitung maseral digital.

Pembuatan blok poles mengacu pada AS (Australian Standard) 2856.2 (1998). Blok poles batubara disiapkan dari sekitar 15 gram conto batubara yang sudah dihancurkan serta lolos saringan $1 \mathrm{~mm}$. Hancuran batubara kemudian dicampur dengan resin epoksi dan dicetak berbentuk lingkaran. Setelah conto mengeras, kemudian digosok menggunakan ampelas nomor 600-1200, kemudian dipoles untuk mendapatkan permukaan conto yang halus dan siap digunakan untuk analisis petrografi. Pengukuran reflektansi vitrinit mengacu pada ASTM D2798 (2011).

Pengukuran dilakukan pada 100 titik pengamatan. Hasil pengukuran kemudian diolah kembali dengan menggunakan perhitungan statistik guna mendapatkan nilai reflektansi vitrinit rata-rata, sedangkan penentuan komposisi maseral pada setiap conto polis blok batubara di bawah mikroskop, dilakukan pada 500 titik pengamatan dengan mode sinar putih dan juga sinar fluoresens. Mode sinar fluoresens digunakan untuk mengidentifikasi maseral liptinit yang tidak semuanya bisa jelas terlihat dengan menggunakan mode sinar putih.

Studi pustaka menunjukkan bahwa batubara di daerah penyelidikan termasuk batubara peringkat rendah, sehingga untuk analisis komposisi maseral, klasifikasi maseral yang digunakan adalah klasifikasi maseral untuk batubara peringkat rendah (ICCP, 2001).

\section{HASIL ANALISIS}

\section{Pengukuran Reflektansi Vitrinit}

Pengukuran reflektansi vitrinit terhadap 13 conto batubara didaerah penelitian menunjukkan nilai $\mathrm{R}_{\bar{v}}^{-} \max \quad 0,25 \%$ s.d. $0,45 \%$ dengan nilai rata-rata $0,38 \%$ (Tabel 1).

\section{Analisis Komposisi Maseral}

Hasil analisis komposisi maseral dan mineral conto batubara di daerah penelitian dapat dilihat pada Tabel 1 dan Tabel 2 . Kelompok maseral huminit $(67,20 \%$ s.d. $95,80 \%$ ) mendominasi komposisi maseral batubara daerah penelitian diikuti oleh kelompok maseral liptinit $(0,20 \%$ s.d. $4,60 \%)$ dan kelompok maseral inertinit $(1,20 \%$ s.d. $26,40 \%)$. Kelompok maseral vitrinit didominasi oleh subkelompok maseral humotelinit $(10,00 \%$ s.d. $72,80 \%)$; sedangkan kelompok maseral 
liptinit didominasi oleh kutinit $(0,20 \%$ s.d. $4,60 \%$ ), sementara kelompok maseral inertinit-didominasi oleh sub maseral teloinertinit (1,40\% s.d. $19,60 \%)$.

Kandungan mineral pada conto batubara teranalisis relatif rendah (rata-rata $<5 \%$ ). Hanya dua conto yang menunjukkan kandungan mineral cukup tinggi (>10\%). Mineral yang paling banyak ditemukan pada conto batubara di daerah penelitian adalah mineral lempung $(0,20 \%$ s.d. $23,80 \%$ ) dan diikuti oleh oksida besi $(0,40 \%$ s.d. $6,00 \%)$.

\section{Perhitungan Nilai TPI dan GI}

Hasil perhitungan nilai TPI dan GI dapat dilihat pada Tabel 3. Nilai TPI untuk conto batubara Formasi Balikpapan di daerah penelitian berkisar antara 0,20 s.d. 3,41 dengan nilai rata-rata 3,03. Pada umumnya hampir semua conto batubara di daerah penelitian memiliki nilai TPI yang relatif sama (3,00 s.d. 3,35$)$, satu conto JGN-23 mempunyai nilai TPI 2,61 sedangkan conto JGN-01 mempunyai nilai TPI yang jauh berbeda yaitu 0,20.

Nilai TPI yang rendah untuk kedua conto batubara JGN-01 dan JGN-23 diperkirakan dengan kandungan mineral pada kedua conto yang relatif jauh lebih tinggi dibandingkan dengan conto batubara lainnya (Tabel 2). Nilai GI untuk conto teranalisis menunjukkan kisaran nilai antara 2,56 s.d. 79,83 .

\section{Perhitungan Nilai GWI dan VI}

Perhitungan nilai GWI dan VI seluruh conto teranalisis dapat dilihat pada Tabel 4. Berdasarkan hasil perhitungan, nilai GWI untuk conto teranalisis di daerah penelitian berkisar antara 0,01 s.d.- 0,45 dengan nilai rata-rata 0,06 , sedangkan nilai $\mathrm{VI}$ untuk conto teranalisis menunjukkan kisaran nilai yang bervariasi antara 0,20 s.d. 3,34 dengan nilai rata-rata 2,79.

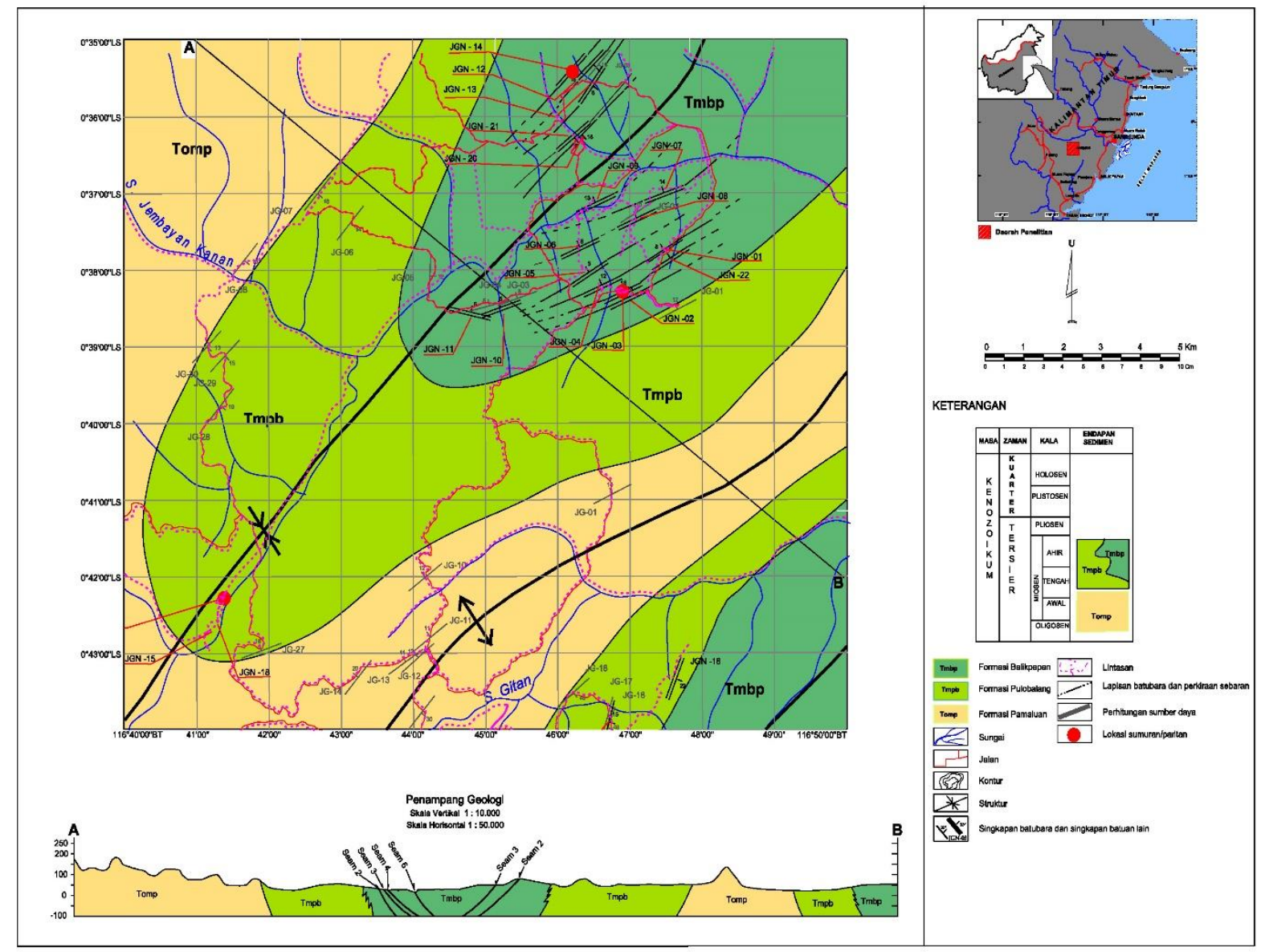

Gambar 3. Peta geologi daerah penelitian (Modifikasi dari Supriatna dkk., 1995) 


\section{MAKALAH ILMIAH}

Tabel 1. Hasil pengukuran reflektansi rata-rata vitrinit dan kelompok maseral.

\begin{tabular}{cccccc}
\hline $\begin{array}{c}\text { No. } \\
\text { Conto }\end{array}$ & Litologi & $\begin{array}{c}\text { Reflektansi } \\
\text { Vitrinit Rata } \\
\left(\mathbf{R v}_{\text {max }}\right), \boldsymbol{\%}\end{array}$ & $\begin{array}{c}\text { Huminit, } \\
\%\end{array}$ & $\begin{array}{c}\text { Liptinit, } \\
\%\end{array}$ & $\begin{array}{c}\text { Inertinit, } \\
\mathbf{\%}\end{array}$ \\
\hline JGN-01 & Batubara & 0,25 & 68,00 & 0,20 & 1,40 \\
\hline JGN-02 & Batubara & 0,33 & 67,60 & 5,60 & 26,40 \\
\hline JGN-03 & Batubara & 0,45 & 87,00 & 5,60 & 6,60 \\
\hline JGN-04 & Batubara & 0,36 & 87,20 & 1,60 & 10,00 \\
\hline JGN-05 & Batubara & 0,36 & 93,80 & 1,60 & 3,20 \\
\hline JGN-07 & Batubara & 0,41 & 88,60 & 5,20 & 5,00 \\
\hline JGN-09 & Batubara & 0,41 & 86,40 & 3,20 & 8,00 \\
\hline JGN-12 & Batubara & 0,45 & 89,80 & 0,80 & 7,80 \\
\hline JGN-13 & Batubara & 0,43 & 87,80 & 1,60 & 9,60 \\
\hline JGN-14 & Batubara & 0,44 & 85,20 & 0,40 & 12,40 \\
\hline JGN-20 & Batubara & 0,38 & 90,60 & 0,40 & 7,40 \\
\hline JGN-23 & Batubara & 0,37 & 84,80 & 0,60 & 2,60 \\
\hline JGN-24 & Batubara & 0,36 & 95,80 & 1,00 & 1,20 \\
\hline
\end{tabular}

Tabel 3. Hasil perhitungan TPI dan GI di daerah penelitian.

\begin{tabular}{ccc}
\hline No. Conto & TPI & GI \\
\hline JGN-01 & 0,20 & 48,71 \\
\hline JGN-02 & 3,39 & 2,56 \\
\hline JGN-03 & 3,33 & 13,18 \\
\hline JGN-04 & 3,34 & 8,72 \\
\hline JGN-05 & 3,41 & 29,31 \\
\hline JGN-07 & 3,29 & 17,72 \\
\hline JGN-09 & 3,37 & 10,80 \\
\hline JGN-12 & 3,10 & 11,54 \\
\hline JGN-13 & 3,31 & 9,17 \\
\hline JGN-14 & 3,40 & 6,87 \\
\hline JGN-20 & 3,41 & 12,24 \\
\hline JGN-23 & 2,61 & 32,62 \\
\hline JGN-24 & 3,18 & 79,83 \\
\hline
\end{tabular}

Tabel 4. Hasil perhitungan GW dan VI di daerah penelitian.

\begin{tabular}{ccc}
\hline No. Conto & GWI & VI \\
\hline JGN-01 & 0,45 & 0,20 \\
\hline JGN-02 & 0,01 & 3,00 \\
\hline JGN-03 & 0,01 & 2,71 \\
\hline JGN-04 & 0,02 & 2,97 \\
\hline JGN-05 & 0,01 & 3,18 \\
\hline JGN-07 & 0,01 & 2,93 \\
\hline JGN-09 & 0,03 & 2,98 \\
\hline JGN-12 & 0,02 & 3,05 \\
\hline JGN-13 & 0,01 & 3,05 \\
\hline JGN-14 & 0,02 & 3,20 \\
\hline JGN-20 & 0,02 & 3,34 \\
\hline JGN-23 & 0,14 & 2,54 \\
\hline JGN-24 & 0,02 & 3,09 \\
\hline
\end{tabular}




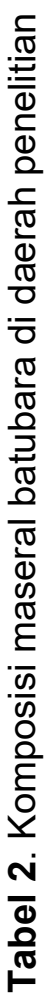

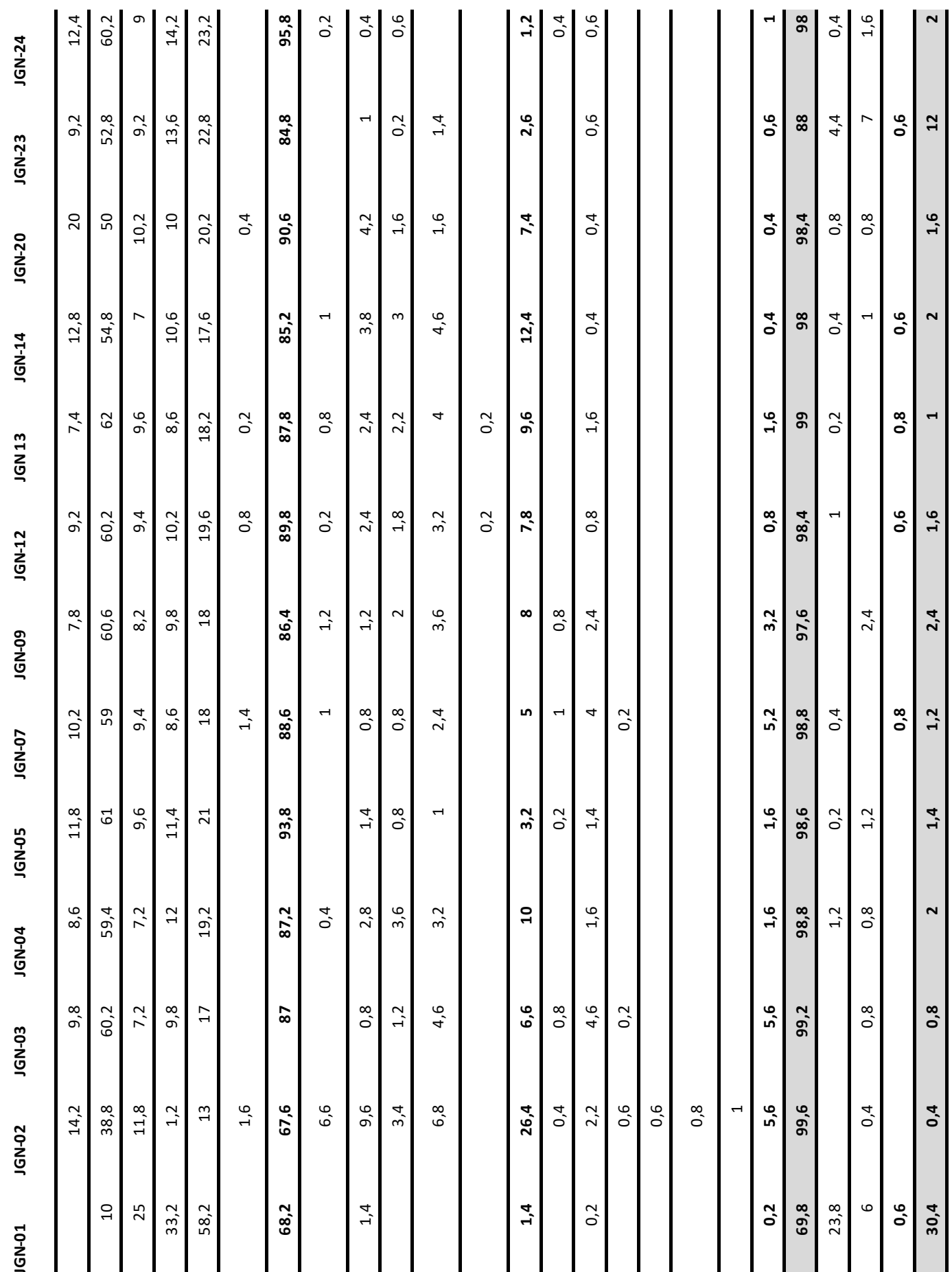

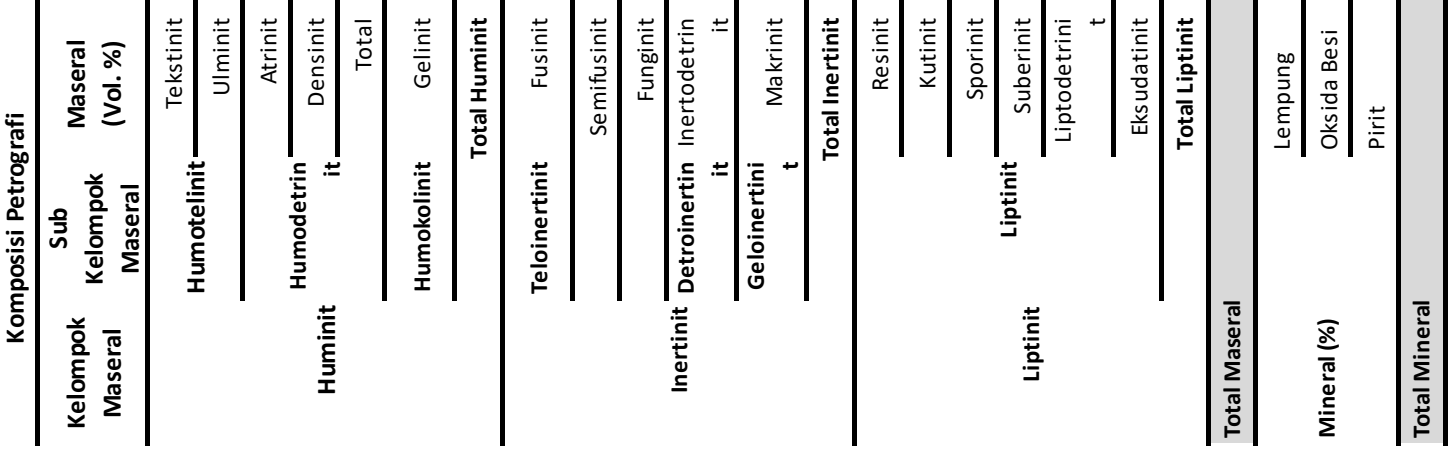




\section{PEMBAHASAN}

Mengacu pada klasifikasi ASTM (1986), berdasarkan hasil analisis reflektansi vitrinit (Rv $0,25 \%$ s.d. $0,45 \%$ ), peringkat batubara di daerah penelitian termasuk pada peringkat lignit - subbituminus (Gambar 4).

Kandungan humotelinit yang dominan serta nilai TPI $>1$ menunjukkan bahwa batubara di daerah penelitian berasal dari tumbuhan kayu. Keberadaan material sub kelompok humotelinit yang lebih banyak dibanding humodetrinit dan humokolinit juga mengindikasikan bahwa derajat pengawetan jaringan sel tumbuhan di daerah penelitian cukup tinggi yang diperkirakan berhubungan dengan lingkungan pengendapan gambut yang selalu dalam kondisi basah dan $\mathrm{pH}$ rendah (Calder dkk., 1991; Diessel, 1992).

Dominasi tumbuhan berkayu sebagai material pembentuk batubara di daerah penelitian juga dikuatkan oleh nilai VI conto batubara di dareah penelitian yang lebih besar dari 3 (Gambar 6). Mengacu pada Calder dkk (1991) nilai $\mathrm{VI}<3,00$ menunjukkan dominasi tumbuhan batang lunak (herbaceous atau marginal aquatic) sebagai material pembentuk batubara sedangkan nilai $\mathrm{VI}>3,00$ mengindikasikan dominasi tumbuhan kayu. Adanya conto batubara mempunyai nilai $\mathrm{Vl}<3$ (Gambar 6) mengindikasikan bahwa batubara di daerah penelitian sebagian kecil berasal dari tumbuhan air yang mempunyai batang lunak (herbaceous).

Kandungan inertinit dan nilai GI dapat menggambarkan tingkat oksidasi yang dialami material pembentuk batubara. Kandungan inertinit yang tinggi kemungkinan disebabkan karena material organik dalam gambut terpapar udara, gambut mengalami pengangkatan ataupun terbakar. Menurut Diessel 1992), rendahnya derajat oksidasi pada lingkungan pengendapan batubara ditunjukkan oleh rendahnya kandungan inertinit serta tingginya nilai $\mathrm{Gl}$.

Secara umum, kandungan inertinit batubara di daerah penelitian relatif rendah $(<5 \%)$. Hanya dua conto yang memiliki kandungan inertinit relatif tinggi yaitu conto JGN-02 (26,04\%) dan JGN-14 (12,40\%) (Tabel 2 dan Tabel 3). Kandungan inertinit yang tinggi serta nilai $\mathrm{Gl}$ yang rendah mengindikasikan bahwa proses oksidasi yang berlangsung pada material pembentuk batubara berlangsung signifikan (Diessel, 1992). Di daerah penelitian, rendahnya kandungan intertinit berasosiasi dengan tingginya nilai $\mathrm{GI}$ (Tabel 2 dan Tabel 3). Secara umum, batubara cenderung memiliki kandungan inertinit rendah dengan nilai GI yang relatif tinggi (Tabel 2 dan Tabel 3). Berdasarkan hal tersebut diatas, disimpulkan bahwa proses oksidasi pada material organik pembentuk batubara di daerah penelitian kemungkinan tidak berlangsung signifikan.

Hasil plot silang antara nilai TPI dan GI dalam diagram hasil modifikasi dari Diessel (1992) serta Amijaya dan Littke (2005), didukung oleh nilai GWI $(<5)$, mengindikasikan bahwa secara umum, conto batubara di daerah penelitian diendapkan pada lingkungan telmatik kecuali conto JGN-01 yang terendapkan pada lingkungan limnik (Gambar 5).

Plot hasil analisis maseral pada diagram modifikasi dari Diessel (1992) serta Amijaya dan Littke (2005), mengindikasikan bahwa gambut di daerah penelitian merupakan tipe ombrotropik yang hanya menerima suplai air hujan sehingga miskin akan nutrisi dan mempunyai kandungan mineral yang rendah (Gambar 6). 


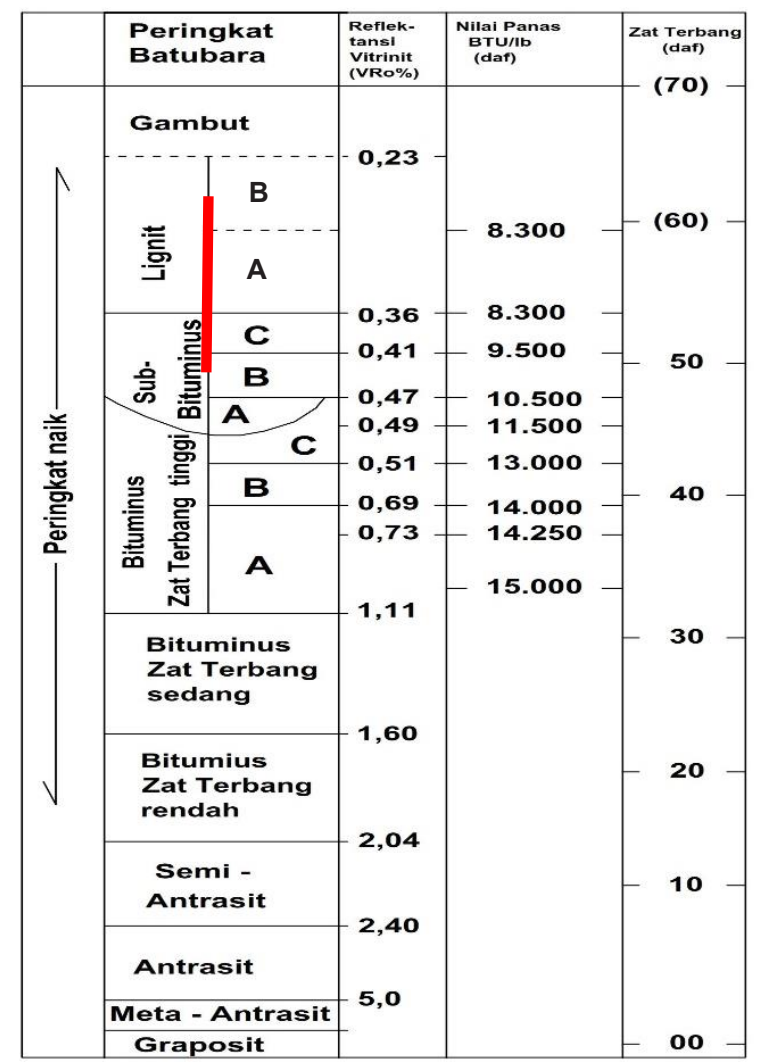

Gambar 4. Peringkat batubara di daerah penelitian (Modifikasi dari ASTM, 1986)

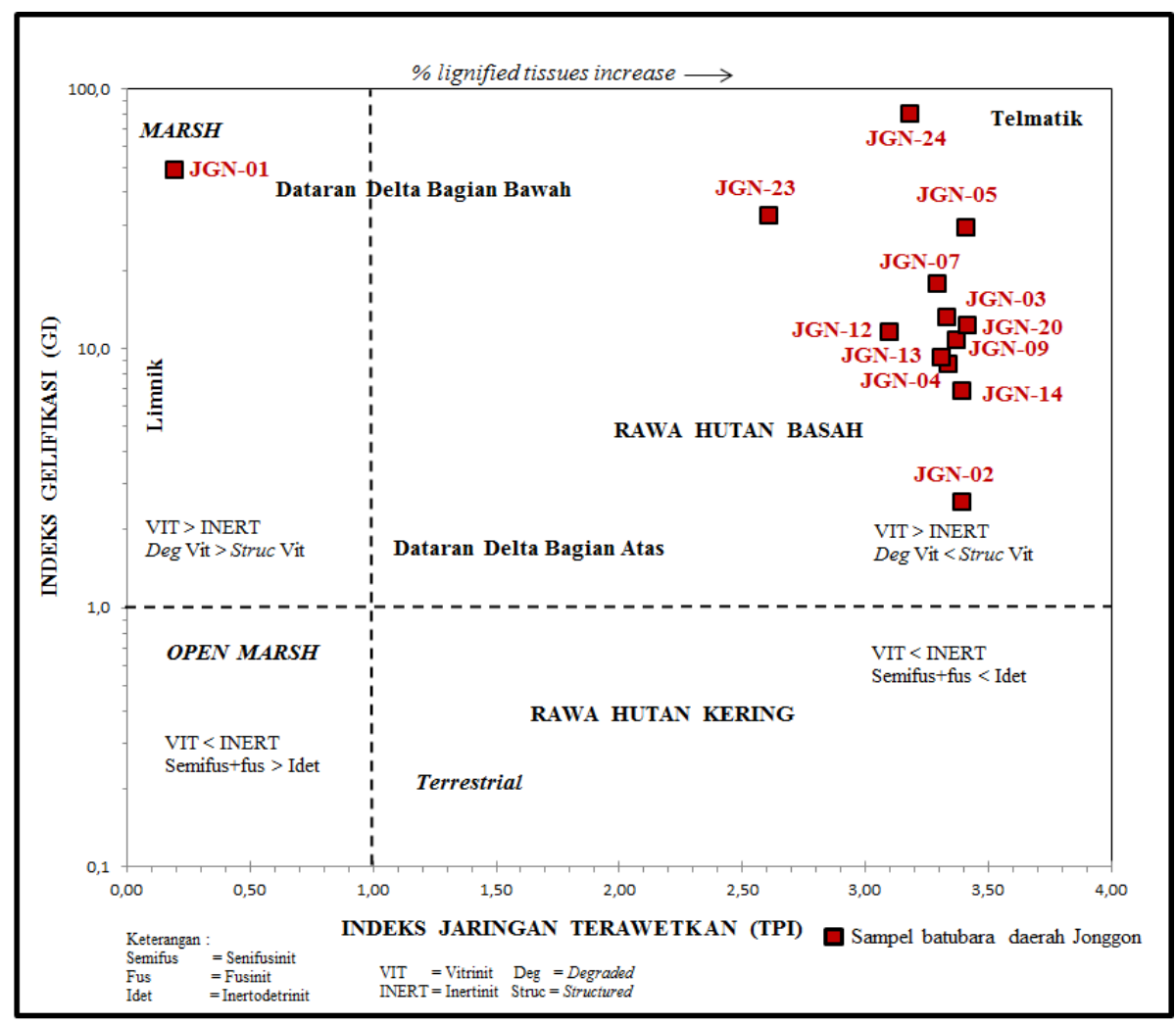

Gambar 5. Plot silang antara nilai TPI dan GI conto batubara di daerah penelitian. Diagram yang digunakan adalah diagram hasil modifikasi dari Diessel (1992) dan Amijaya dan Littke (2005) 


\section{MAKALAH ILMIAH}

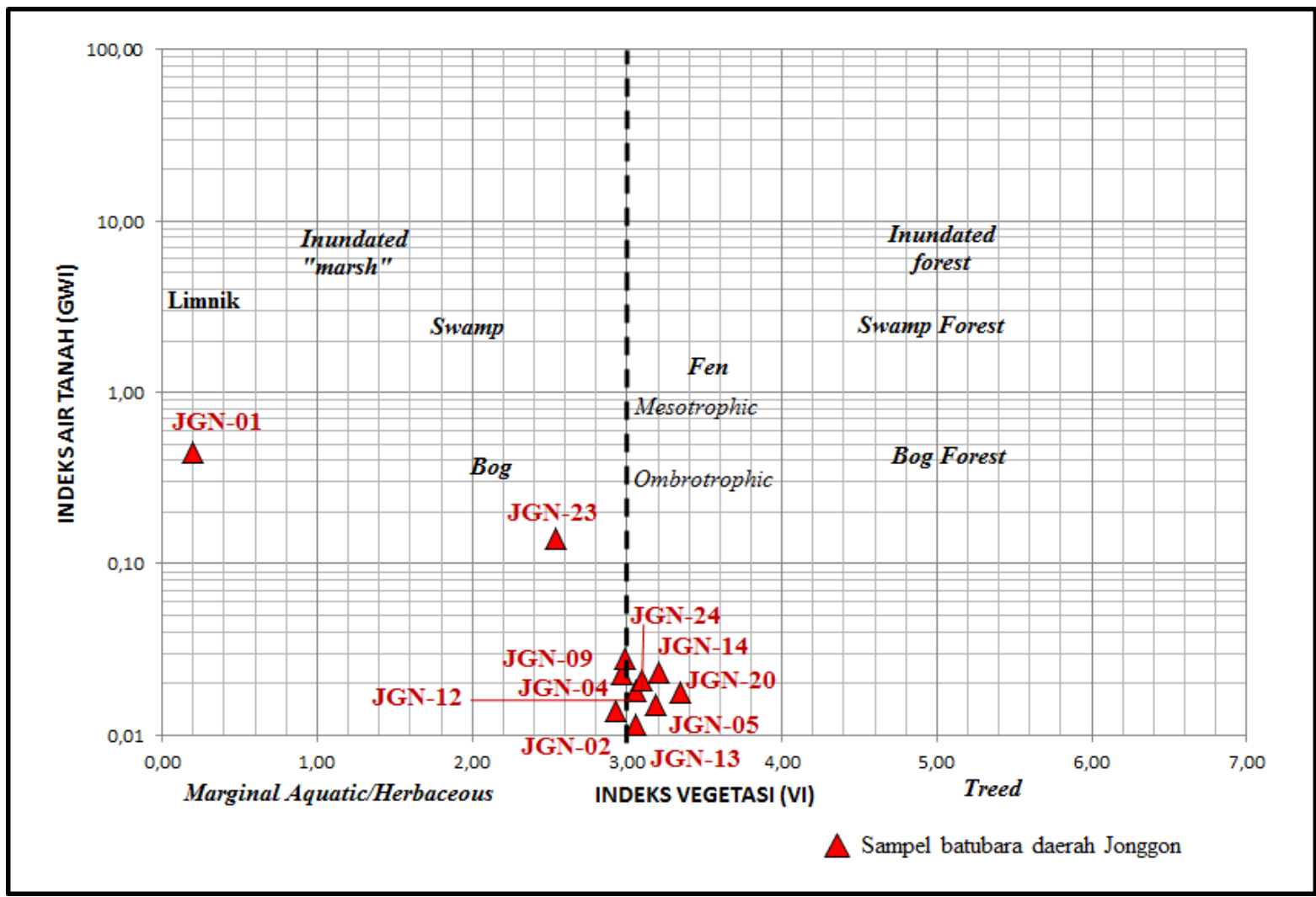

Gambar 6. Plot silang antara nilai GWI dan VI conto batubara di daerah penelitian. Diagram yang digunakan adalah diagram hasil modifikasi dari Amijaya dan Littke (2005)

\section{KESIMPULAN}

Berdasarkan hasil analisis petrografi, batubara Formasi Balikpapan di daerah penelitian mempunyai nilai $\mathrm{Rv}$ yang termasuk pada peringkat lignit subbituminus dengan komposisi kelompok maseral terdiri dari huminit $(67,20 \%$ s.d. $95,80 \%)$, inertinit $(1,20$ s.d. 26,40$)$, dan liptinit $(0,20$ s.d. 5,60$)$.

Batubara di daerah penelitian sebagian besar berasal dari tumbuhan berkayu yang ditunjukan oleh tingginya kandungan huminit, nilai rata rata TPI $>1$ serta nilai VI>3. Material organik pembentuk batubara tidak mengalami tingkat oksidasi yang signifikan ditunjukkan oleh kandungan inertinit yang rendah serta nilai GI yang relatif tinggi.

Plot silang TPI terhadap GI dan GWI terhadap VI mengindikasikan bahwa batubara terendapkan pada lingkungan telmatik, sedangkan tipe gambut pembentuk batubara termasuk dalam tipe ombrotropik.

\section{UCAPAN TERIMA KASIH}

Penulis mengucapkan terima kasih kepada Pusat Sumber Daya Mineral, Batubara dan Panas Bumi, Badan Geologi, Kementerian Energi dan Sumber Daya Mineral yang telah membantu dalam pembiayaan kegiatan penelitian ini.

\section{DAFTAR PUSTAKA}

Amijaya, H. dan Littke, R., (2005): Microfasies and depositional environment of Tertiary Tanjung Enim low rank coal, South Sumatra Basin, Indonesia. International Journal of Coal Geology, 61, 197221.

AS 2856.2 (1998): Coal petrography part 2: Maceral analysis, Standards Association of Australia, The Crescent, Homebush, NSW. 
ASTM D2798 (2011): Standard test method for microscopical determination of the vitrinite reflectance of coal, PA.

ASTM (1986): Annual book of ASTM standards, American Society for Testing and Materials, Philadelphia, 388, PA.

Baihaqi, A., Susilawati, R., Fauzielly, L., dan Muljana, B., I. (2017): Studi perbandingan karakteristik kimia dan petrografi batubara lapangan $\mathrm{x}$, Cekungan Sumatera Selatan dan lapangan y Cekungan Sumatera Tengah, Indonesia, Buletin Sumber Daya Geologi, 12, 87-102, Pusat Sumber Daya Mineral Batubara dan Panas Bumi, Bandung.

Calder, J. H., Gibling, M. R., dan Mukopadhyay, P. K., (1991): Peat formation in a Westphalian B piedmont setting, Cumberland Basin, Nova Scotia: implications for the maceral-based interpretation of rheotrohic and raised paleo-mires: Bulletin de la Socie'te' Ge'ologique de France, 162/2, 283-298.
Cook, A. C. (1982): The origin and petrology of organic matter in coal, oil shales and petroleum source rocks, University of Wollongong, Wollongong, New South Wales.

Diessel, C. F. K. (1992): Coal-bearing depositional systems, SpringerVerlag, Berlin, Heidelberg.

ICCP (2001): The new inertinite classification (ICCP System 1994), Fuel, 80, 459-471.

Satyana, A. H., Nugroho D., dan Surantoko I. (1999): Tectonic controls on the hydrocarbon habitats of the Barito, Kutei, and Tarakan Basins, Eastern Kalimantan, Indonesia: major dissimilarities in adjoining basins, Journal of Asian Earth Sciences, 17, 99-122.

Supriatna, S., Sukardi, dan Rustandi, E. (1995): Peta geologi lembar Samarinda, Kalimantan. Pusat Penelitian dan Pengembangan Geologi, Bandung-Indonesia.

Stach, E., Malkowskey, M-Th., Teichmuller, M. Taylor, G. H., Chandra, dan D. Teichmuller (1982): Stach's textbook of coal petrology, Edisi 3, Gebruder Borntreger, Berlin Stuggart, 535.

\begin{tabular}{|ll|}
\hline Diterima & $:$ 12 September 2017 \\
Direvisi & $: 29$ Oktober 2017 \\
Disetujui & $: 31$ Agustus 2018 \\
\hline
\end{tabular}

